\title{
"A Good Imagination Gone Wrong": Reading Anne of Green Gables as a Quixotic Novel
}

DOI

https://doi.org/10.32393/jlmms/2019.0003

Published on

Wed, 06/05/2019 - 09:00

This study examines Anne of Green Gables as a quixotic novel by considering how the novel's rhetoric of a performance of authorship embodies moral, aesthetic, and critical stances toward reading.
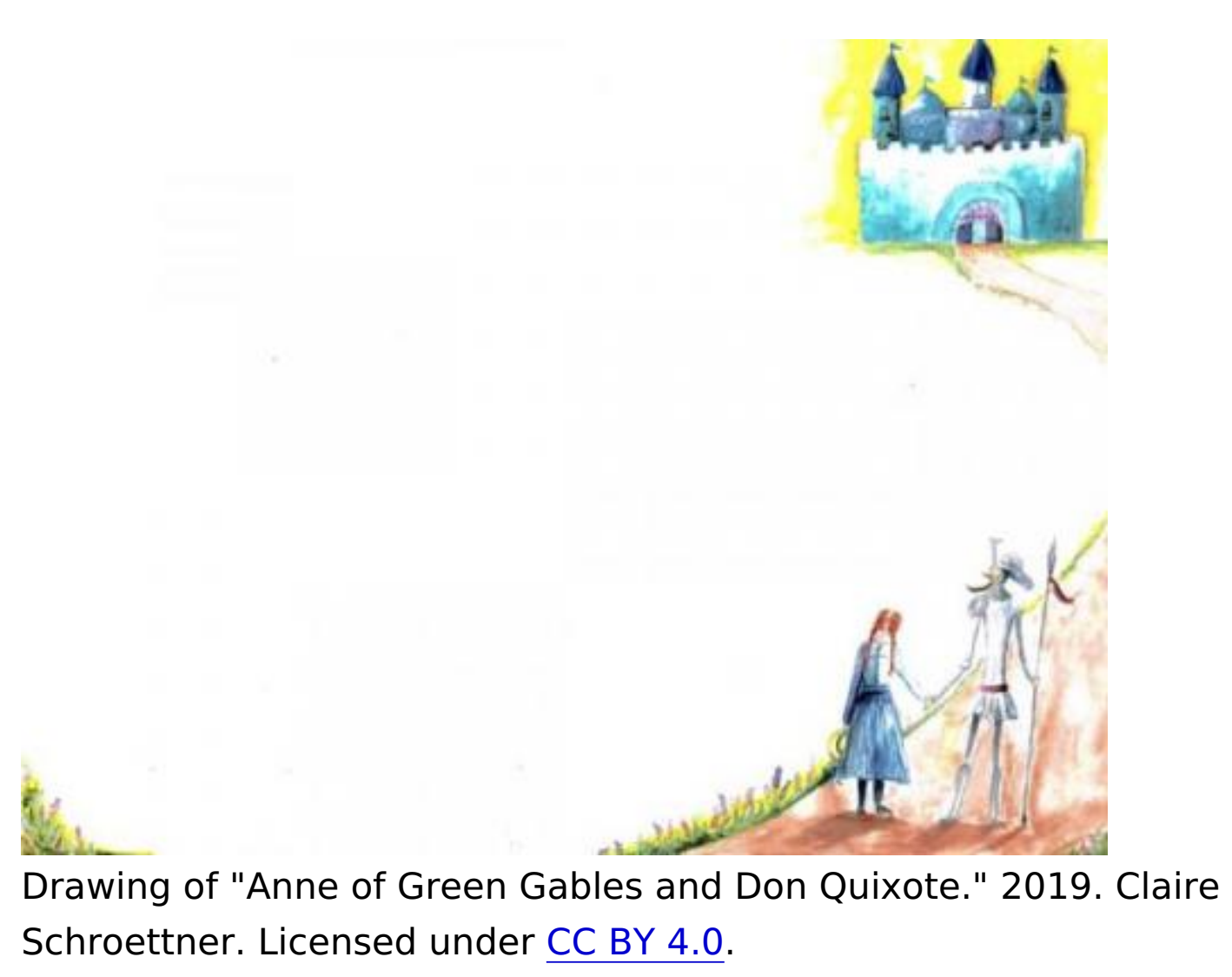
L.M. Montgomery wove her passion for reading and writing into her unforgettable heroine, Anne Shirley, a book lover whose imagination and penchant for the romance of literature repeatedly threaten to blur the line between fact and fiction. Much like Cervantes's Don Quixote, Anne is rarely content with only reading romantic literature, instead introducing reading into her own world through intertextual references, through discussions of reading, and by enacting readinginspired adventures, often to her own detriment. Although Anne, a reader-turnedperformer of literature, shares much in common with the infamous tilter at windmills, the similarities extend beyond their affinity for chivalrous romance and their attempts to emulate fictional characters as authors of their own narratives. A study of Anne of Green Gables as a quixotic novel reveals how Montgomery employs a performative rhetoric to explore the creative process of writing and to project moral, aesthetic, and critical stances toward reading.

In her study of English quixotic novels, Dorothee Birke identifies the concepts of the performance of authorship and the projection of reading stances as central to understanding how these works elicit critical reflection on both the creation and the reception of texts.1 For Birke, this performance consists of the rhetorical attitude taken by an author toward her audience, a stance that gives preference to a text's portrayal of the process and act of communication. The framing of "authorial narration as a performance of authorship means seeing it as a process which foregrounds the logic of a text's production instead of focussing on the figure of the narrator as a personalized entity with distinct abilities, values and opinions." 2 This approach acknowledges the author's anticipated audience, a readership fashioned by social and cultural constraints, and considers the posture taken toward that audience as revealed through the writing process. The authorial audience is an active participant in the construction of the narrative, since it "does not just react to the teller's communication; instead the audience and its unfolding responses significantly influence how the teller constructs the tale." 3 The work of literary creation is thus understood as an undertaking that is ultimately public in nature. 4 Like Birke, I am less interested in questions of differentiating between author and authorial narrator than in how the authorial voice "(re)produces the structural and functional situation of authorship." $\underline{5}$

The concepts of the performance of authorship and the projection of reading stances that Birke applies to the novels in her study draw on previous approaches to reading 
the quixotic plot as a work concerned with authorship and reflective reading. Although quixotic protagonists are voracious readers, this is not their defining trait; rather, it is their performance of literature, "how they read and how they try to shape their lives according to what they read." 6 Quixotic characters' efforts to reinvent themselves are no mere mimesis; rather, they represent the authority with which these readers seek to determine their own actions and identities. 7 Don Quixote's performance of chivalric literature intensifies uncommon behaviour and highlights his "will to self-creation by self-expression." $\underline{8}$ This "quixotic fallacy" is not a condemnation of fiction, but, rather, "an index of the unreliability of readers in their relations to what they read." $\underline{9}$ These novels, therefore, portray specific reading stances as models for reading and reflecting on fiction.

Both the narrative structure and techniques of Don Quixote prioritize Birke's concepts, for they "entice the reader to share in the creative process and bring out the meaning of the text." 10 Throughout both volumes of Cervantes's novel, the narrative voice constantly intrudes in the action and often addresses the reader, further underscoring the fiction in which she has become involved to elicit an active response. The interpolated novels in Don Quixote fulfill this same objective of interrupting the story to encourage a reaction.11 George Haley points to the Maese Pedro puppet show episode as analogous to the overall novel by studying the interplay between puppet master, performance, and spectator.12 Maese Pedro pulls the strings to manipulate his characters while his assistant narrates and interprets the tale, adding his own commentary at times. Meanwhile, the puppet master interrupts his assistant to critique his narration and responds to Don Quixote's criticisms. As a spectator, Don Quixote interrupts the show several times with comments, objections, and corrections. Ultimately, Don Quixote becomes so entangled in the plot that he attacks the characters and destroys the retablo.13 Like this episode, the novel reveals the relationship between the conscious process of writing and the creative and reflective response of reading.

I will focus my reading of Anne of Green Gables as a quixotic novel on the ways authorship is performed with the domestic romance audience in mind, and how its quixotic plot portrays "reading as an embodied act" 14 to enact three stances toward reading that call on readers to contemplate their own role as consumers of fiction. This approach challenges the notion that Anne's mishaps "all teach a similar lesson: adopting romance formulas as a basis for real life results in a mortifying comeuppance" through "pure comic romance." 15 Rather, I argue that the quixotic 
structure highlights the protagonist as a "self-authorizing" and "self-chronicling actor" 16 who performs, time and again, the role of female creator. Anne's enactments of romantic literature as well as the stories she tells draw our attention to the creative processes of authorship and serve as an indication that the novel "is self-consciously acknowledging, but also transcending, the genre of popular romance." 17 This allows the novel to circumvent the limits of that genre's conventions and address broader social and cultural issues.18 As Mary Rubio has accurately observed, women writers of Montgomery's time felt apprehensive about their roles as authors within the patriarchal atmosphere of their era, and they embraced a variety of tactics to sidestep reproach; in this way, women writers of popular fiction managed to challenge the ideologies that informed and shaped their culture despite the restrictions imposed by the very genres within which they worked.19 Montgomery's melding of the domestic romance with the quixotic plot allows her to feign compliance with the established norms of her society while interweaving "a counter-text of rebellion for those who were clever enough to read between the lines." $20 \mathrm{I}$ argue, then, that the quixotic plot encourages active reading and reflection, and this deeper participation on the part of the reader results from the attitudes toward reading projected in the novel.21 These stances equip us not to avoid fiction, but, rather, to consume it appropriately for what it is.22 In this way, Montgomery takes advantage of the popular genre of domestic romance and projects reading stances that call into question "all of the prevailing ideologies which her early 20th century audience demanded." 23 Together, these elements create a rich text that moves beyond the surface-level domestic romance, romantic parody, or criticism of obsessive reading. Montgomery's novel takes her quixotic protagonist as a point of departure to contemplate the creative process as well as different stances toward reading, thus illustrating the reader's "status as an active producer of meaning rather than only a passive consumer." 24

\section{"That's a Sentence I Read in a Book Once": Anne Shirley as a Female Quixote}

Miguel de Cervantes's Don Quixote25 serves as the blueprint for the character of the avid reader whose reading impacts his sense of reality. The novel recounts the adventures of Alonso Quixano, a hidalgo, or a gentleman of the lesser nobility, who reads chivalrous romances to escape his confining reality. He spends "sleepless nights trying to understand them and extract their meaning," becoming so immersed in that fictitious world "that for him no history in the world was truer." 26 
His grasp of the line between fiction and reality fades, and "when his mind was completely gone, he had the strangest thought any lunatic in the world ever had ... to become a knight errant and travel the world with his armor and his horse to seek adventures and engage in everything he had read that knights errant engaged in." 27 Of course, his story is ultimately a series of misadventures that leave the poor knight beaten, bruised, and forcibly returned home at the end of the first book. In the second volume, published in 1615, ten years after the first, Don Quixote learns about the publication of his first adventures, and he sets out again, but, this time, he constantly finds himself in the presence of those who have read about his first exploits as well as Avellaneda's unauthorized sequel. It is Don Quixote's insistence on transposing the fictitious world of chivalrous novels onto mundane realities that leads him to undertake feats doomed to failure and that underscore the complexity of the processes of both reading and writing.

Don Quixote has been the model for a variety of representations of readers addicted to fiction. Although the quixotic character is fundamental to such novels, a fully developed quixotic plot is more complex. The quixotic novel consists of a protagonist who is a voracious reader and whose reading reshapes her understanding of the world around her. As a result, the main conflict revolves around the protagonist's altered comprehension of the world. Reading is portrayed as a practice and habit of conduct, and the quixotic novel features a wealth of intertextual allusions and quotations. These intertextual references accentuate the enactment of reading, as both the characters and the authorial narrator weave them into the reality of the novel. These allusions place the quixotic novel itself squarely within the cultures and customs of reading and discussing reading.28 As the protagonist of a quixotic plot, Anne Shirley is an avid reader who views the world through the lens of romantic literature. Reading is an integral part of Anne's life-a learned behaviour, and one she discusses with a variety of other characters. Like Don Quixote, Anne of Green Gables consists of a series of adventures whose conflicts arise from Anne's attempts to embody the worlds about which she reads. Rea Wilmshurst has identified over forty literary allusions in the novel, spread among narratorial commentary, intertitles, and the words of the characters themselves, 29 and they situate the novel within the practice of literary consumption and discussion.

Numerous women populate novels in the quixotic tradition, among them Arabella in Lennox's The Female Quixote (1752), Catherine Moreland in Austen's Northanger Abbey (1817), Emma Bovary in Flaubert's Madame Bovary (1856), Gerty MacDowell 
in Joyce's Ulysses (1922), and Briony Tallis in McEwan's Atonement (2013). Each of these characters is "a heroine whose head has been turned by over-reading [...] and perceives the world refracted through the prism of her fictional code." 30 Anne Shirley figures among these quixotic heroines who "seek to replace their mundane lives devoid of excitement, happiness, and/or fulfilment with the fantastic and romanticized world offered by the books that have sparked a new fire in their wild imaginations." 31 Indeed, Anne's vivid imagination, which is constantly fed by her insatiable reading, remains one of her most endearing and enduring characteristics. Orphaned as an infant, Anne has not belonged to anyone, and, instead, is taken in and must work for two families before being sent to an orphanage. Books and Anne's imagination have been her saving grace in these alienating settings, and, despite the ugly realities she has lived, Anne has become adept at escaping them by enacting the worlds about which she reads. Like Don Quixote himself, she is particularly enthralled with chivalrous romance. In fact, "Anne was devoured by secret regret that she had not been born in Camelot. Those days, she said, were so much more romantic than the present."32 It is therefore fitting that CBC's 2017 television series Anne with an $E$ quotes the opening lines from Don Quixote when Marilla asks for her personal background.33 Anne is a consumer of the fictions and fashions printed in books and popular magazines, and these romantic texts shape her interactions with the world around her.34 Unlike Lennox's Arabella, Anne has not lived an isolated existence; rather, she has seen too much of the world, and it is the ugliness of her realities that encourages her flights of fancy as informed by her reading of fictional narrative and poetry.

Matthew Cuthbert's and our first introduction to the unexpected arrival at the Bright River station alerts us to Anne's romantic reading of her world: "You could imagine you were dwelling in marble halls," 35 she remarks of her determination to sleep in the wild cherry tree should Matthew not arrive. The iconic drive to Green Gables is defined by Anne's imagination, fed by her consumption of romantic literature, which interprets the physical world for her. She imagines a bride in a wild plum tree, friends in the trees at the orphanage, and herself outfitted in a silk dress. 36 Anne admits to having pinched herself "black and blue from the elbow up" 37 to differentiate between the world of her imagination and her dream come true of finally finding a home. To use Anne's own words, this propensity for "'imagining things different from what they really are" 38 is what leads this quixotic protagonist into one scrape after another throughout the novel. 
Although Anne hardly seems the heroine of a romantic novel to herself, the redheaded orphan girl mistakenly sent to the Cuthberts instead of a boy actively seeks to enact the romance of literature as author of her own narrative. This performance of literature, the way quixotic characters attempt to mould their own lives based on the stories they read, has as a primary aim the alteration or creation of realities and identities.39 Anne Shirley, like Don Quixote, is an outsider for whom reading fashions a place to belong and to live more fully. 40 As Oriel has observed of Don Quixote, the knight's unshakable faith in the power of the performative to portray a new identity is such that he propounds a new vision of the definition of self: no longer is one's identity determined by blood, but, rather, it can be enacted.41 Anne, too, seeks to perform and create her own identity, rather than to bear the label of "orphan."

As part of this performance, Anne is attuned to the significance of names as she rewrites and transforms herself and the physical world with fanciful and carefully selected appellations as author and creator of her own story. Just as Don Quixote's real name is not pinned down, Anne goes unnamed for the ride home from the train station, since it never occurs to Matthew to request that information of the little waif awaiting him. Then, when Marilla at last inquires, Anne aims to name herself: "Will you please call me Cordelia?" she requests of Marilla upon meeting her. "Anne is such an unromantic name." 42 The request declined, she still insists, "if you call me Anne please call me Anne spelled with an e." 43 Once her place at Green Gables is assured, Anne identifies herself with her new home: "it's a million times nicer to be Anne of Green Gables than Anne of nowhere in particular, isn't it?" she observes.44 This epithet smacks of romance and provides Anne with an identity that recalls titles of nobility.45 Anne's creative acts do not stop at her own name, for she revels in lighting on the perfect sobriquets for places, too. These labels allow her to claim her surroundings as locales worthy of a romantic story and to make them her own. 46 By the morning after her arrival at Green Gables, Anne has dubbed the cherry tree "The Snow Queen" and Marilla's geranium "Bonny." 47 As Anne explores further out, the christenings continue, and she populates the landscape with names inspired by her reading in an attempt to refashion her surroundings into the setting of her own romantic story: the Dryad's Bubble, Idlewild, Willomere, Lover's Lane, the Haunted Wood, Violet Vale, and the Birch Path. 48 Anne is so adept at thinking up such names that she reports, "Diana says she never saw the beat of me for hitting on fancy names for places." 49 The power of this performative speech ultimately lies in others' acceptance of and references to the rechristened landscape with Anne's new 
names as those names "become part of the geography of the narrated text." $\underline{50}$

The quixotic protagonist seeks to supersede "the virtual existence of print: he longs actually to live in a romance world" 51 by embodying reading. From the moment we meet Anne at the Bright River train station and hear her determination to sleep in the wild cherry tree, we realize that she, like Don Quixote, looks on the everyday world through the lens of her romantic reading. Anne's yearning to imprint the quotidian world with romantic fiction leads her into countless mishaps that, while mostly less dangerous than the misadventures of Don Quixote, are every bit as unromantic. While, unlike Don Quixote, Anne rarely believes the products of her imagination-the Haunted Wood episode being the primary exception52-her daydreaming and desire to inscribe reality with romance do get her into a considerable amount of trouble. From imagining herself as the perfect hostess and inadvertently intoxicating Diana by overacting in this role, $\underline{53}$ to attempting unsuccessfully to walk the ridgepole of the Barrys' kitchen roof because "[her] honour is at stake," $\underline{54}$ from the failed attempt to dye her red hair black $\underline{5}$ to her frustrated re-enactment of Tennyson's “Lancelot and Elaine," $\underline{6}$ Anne's attempts at emulating the honour, beauty, and drama of romantic literature are a decided flop. Experiencing such failure is an essential characteristic of the quixotic character, 57 and this undercuts the common themes of the very genre the Quixote emulates.

Anne's attempts to inscribe the physical world with the romance of fiction flavour her speech and consciously and subconsciously inform her actions. Her outburst at Mrs. Lynde's comments about her hair reveals the importance Anne places on individual honour and dignity, as in chivalrous literature. To please Matthew, Anne relents and agrees to apologize to Mrs. Lynde, delivering a convincing performance: “Mournful penitence appeared on every feature. Before a word was spoken Anne suddenly went down on her knees before the astonished Mrs. Rachel and held out her hands beseechingly." 58 Marilla is mortified to discover that Anne relishes the drama of her own performance and "was actually enjoying her valley of humiliation-was revelling in the thoroughness of her abasement." 59 Later, when Anne provides a coerced false confession about losing Marilla's brooch, she enacts a scene that meets her satisfaction as a romantic heroine: "I thought out a confession ... and made it as interesting as I could." 60 Anne's vow of friendship with Diana-spoken with clasped hands over a garden path they pretend is running water $\underline{61-i s ~ a ~ p h y s i c a l ~ a n d ~ v e r b a l ~ e n a c t m e n t ~ o f ~ s c e n e s ~ i n s p i r e d ~ b y ~ h e r ~ r e a d i n g . ~ A n n e ~}$ seasons her "eternal farewell" $\underline{62}$ to Diana following the raspberry cordial incident 
with performative utterances aimed not only at inscribing meaning to the moment but making it more romantic as well. "I used the most pathetic language I could think of and said 'thou' and 'thee'," she later reports to Marilla of this parting; "'Thou' and 'thee' seem so much more romantic than 'you.'" 63 Despite being separated from her bosom friend, Anne finds consolation in the romance of their farewell.64 Anne also sees the drama in her winter evening dash to help cure Diana's younger sister: "Anne, although sincerely sorry for Minnie May, was far from being insensible to the romance of the situation." 65 Later, when Mr. Bell cuts down the trees that had formed Anne and Diana's Idlewild playhouse, Anne "sat among the stumps and wept, not without an eye to the romance of it." 66 Anne's view of romance, however, refuses to expand to acknowledge it where it truly is: in Gilbert's saving the rose that falls from her hair at the school concert, 67 or his rescue of her during her failed portrayal of the Lily Maid. 68 Like Lennox's Arabella, Anne feels obliged to defend her honour by defying Gilbert to truly speak of or even insinuate a real romance.

Actual performances and the language of performance in narratorial commentary further draw our attention to performativity in the novel. The authorial narrator observes of Marilla following Anne's outburst to Mrs. Lynde that "[s] dismay over the scene that had just been enacted." 69 Anne's fit of temper when Gilbert calls her "Carrots" is likewise described as a spectacle: "Avonlea school always enjoyed a scene ... Tommy Sloane let his team of crickets escape him altogether while he stared open-mouthed at the tableau." 70 In these examples, Anne's affinity for chivalrous romance predisposes her to heated defences of her own personal dignity. Given her proclivity for embodying her own reading, it is no surprise that Anne also relishes actual public performances. She is thrilled to participate in Miss Stacy's fundraiser concert and, for her, life after the concert loses much of its tang. 71 Later, when Anne recites at the White Sands Hotel benefit as a young woman, she is again "deliciously athrill with the excitement of it." 72 Together, these performances portray reading as an embodied and not merely a cognitive act, and they reiterate Rosenblatt's assertion that " $[t]$ he reader of a text who evokes a literary work of art is, above all, a performer, in the same sense that a pianist performs a sonata, reading it from the text." $\underline{73}$

\section{“It's So Much More Romantic to End a Story with a Funeral Than a Wedding": A Performance of Authorship}


Stephen Railton argues that authorial literary performance is both self-aware of its given audience and self-conscious of the process of literary creation. 74 The quixotic plot reflects these anxieties through a performance of authorship, following Cervantes's original model of an embedded consciousness of the creative process. This is achieved in part through a multi-layered narrative structure that draws attention to the fictitious construct of the novel. In Don Quixote, we discover at the end of Chapter 8 (Book I) that the original author of the knight's adventures was an Arabic historian, Cide Hamete Benengeli. A second author identifies himself as the reader of the first chapters, admitting that he discovered the remaining chapters in Arabic in a market in Toledo and had to hire a translator, himself unreliable, to render the manuscript in Spanish.75 The interpolated novels also interrupt the action to highlight the creative process of narration and to stimulate an engaged response from the reader.76 While the chivalrous romances attempt to pass themselves off as history, Cervantes is intent on revealing the presence of the creator-much like the puppet master, Maese Pedro, in Book II. 77

Behind Anne Shirley, there is another puppet master pulling all the strings, another author performing her craft and well aware of her intended audience. Each precisely titled chapter relates another adventure for the quixotic female protagonist who sallies forth to construct her identity as Anne of Green Gables in her new-found home. These intertitles form part of what Gérard Genette identifies as the paratext, those imprecise areas that are "a zone not just of transition, but of transaction" 78 and that negotiate meaning between the audience and the text itself. Intertitles may vary from the humorous Cervantine model that summarizes what will transpire in the chapter to succinct intertitles to numbers or to none at all; whatever their form, they draw our attention to the authorial voice that selects and inscribes them. 79 In Anne of Green Gables, the intertitles follow the Cervantine model of summarizing and setting expectations, although in an abbreviated form. The first three chapters' titles 80 prepare us, like Mrs. Lynde, Matthew, and Marilla, to be surprised, and highlight the authorial awareness of audience. The narratorial commentary, "those speech acts by a narrator that go beyond providing the facts of the fictional world and the recounting of events," 81 further underscores the author as performer. We are conscious of the authorial narrator's role in constructing the text before us in her observations of the thoughts and behaviour of the brook as it passes Mrs. Lynde's home.82 Like Mrs. Lynde herself, positioned at the strategic vantage point of her window with her "all-seeing eye," 83 the authorial narrator is clearly present in the very story she delivers. She anticipates her audience's reaction to Anne's arrival in 
her portrayal of Mrs. Lynde as thinking "in exclamation points" $\underline{84}$ upon learning of the Cuthberts' intention to adopt an orphan boy. She hints at the surprise awaiting Matthew at the station, 85 empathizes with the ugliness Anne has endured, 86 and even reveals that Anne fails to follow all of Marilla's directives by forgetting to air the bed on her first morning at Green Gables.87 Narratorial comments also remind us of the limits of writing. The image of the sea on the buggy ride from Bright River includes a description of its "many shifting hues," with "elusive tintings for which no name has ever been found." 88 Likewise, the plain gable room given to Anne is "of a rigidity not to be described in words." 89 The commentary reveals the authorial narrator's role as the discretionary documenter in the Bildungsroman she is writing when she mentions in passing a list of Anne's minor scrapes that she deems too insignificant to relate in detail. 90 The authorial narrator's observation that "all the silly things that were done in Avonlea that summer because the doers thereof were 'dared' to do them would fill a book by themselves" 91 highlights her selectivity in what she does include.

The performance of authorship is also depicted by the characters themselves. Anne is never at a loss to tell or invent a romantic story, some of which even move her to tears. 92 Anne's ability to retell and (re)create fiction supports creative licence, since she admits to inventing her own ending to a story when she forgets the original version. 93 Rubio has described Anne as an "artist" who "creates a new reality," not only for herself, but for all those around her.94 In addition to her own private daydreams, Anne shares stories and events from daily life with others. Often, she interlaces these narrations with commentary as she relates those fancies and admits how they collide with daily life. From forgetting to put flour in a cake $\underline{95}$ to finding a mouse drowned in the pudding sauce she fails to cover because of her daydreams, 96 to burning up a pie warming in the oven because of her reveries of knights and princesses, 97 Anne's narrated mishaps parallel the narratorial commentary of the novel.

The Story Club that Anne and her friends begin also encourages conversations about the writing process and about their intended audience. In fact, Waterston argues that the Story Club element "is the mark of Montgomery's assurance as creator of fiction." 98 Anne's story, "The Jealous Rival; or In Death Not Divided," is her own romantic effort to write a love story worthy of the genre of domestic romance. 99 However, her own experience is so lacking that she must turn to outside sources (the eavesdropping Ruby Gillis) to know how to write the proposal scene; when the 
requested suggestion fails to meet her expectations, she imagines it for herself instead. Anne interrupts her retelling of her own story of Malcolm Andrews's unromantic proposal to Ruby Gillis's older sister with narratorial commentary, just as we see her do throughout the novel. Despite this romantic information, Anne prefers to kill off her characters, observing, "It's so much more romantic to end a story with a funeral than a wedding." 100 Indeed, Anne's commentary on the creative process foreshadows the novel's own ending in Matthew's death and the postponement of a romantic relationship between Anne and Gilbert.101 The guiding influence of Miss Stacy also encourages conversations and reflection on the writing process. Under her tutelage, Anne recognizes the incompatibility between the worlds she attempts to create, as informed by her reading, and the world in which she lives: "It was silly to be writing about love and murder and elopements and mysteries. Miss Stacy ... won't let us write anything but what might happen in Avonlea in our own lives." 102 This commentary reflects the creative production of the novel itself, which contains nothing but what might have happened in the fictional setting of Avonlea and the lives of the characters who inhabit it.

The authorial narrator's commentary regarding Marilla is especially insightful to the concept of a performance of authorship. She introduces Marilla as "a woman of narrow experience and rigid conscience," observing that "there was a saving something about her mouth which, if it had been ever so slightly developed, might have been considered indicative of a sense of humour." 103 The process by which Marilla's personality thaws is directly related to Anne's attempts (and ultimate failures) to embody reading. Anne's melodramatic reaction to being told the Cuthberts expected a boy brings out on Marilla's face "a reluctant smile, rather rusty from long disuse." 104 As the novel progresses, Marilla is constantly containing both smiles and laughter at Anne's interpretation of the world of Avonlea as well as her failed attempts to enact reading in that world. It is, in fact, Anne's tears over the future she writes in her imagination of Diana as a married woman who will leave her bosom friend that finally cause Marilla to "burst into ... a hearty and unusual peal of laughter." 105 Although Marilla chastises Anne for her candid assessment of other characters, she admits to herself that she has read them in the same way. Duty urges Marilla to reprimand Anne, but she "was hampered by the undeniable fact that some of the things Anne had said, especially about the minister's sermons and Mr. Bell's prayers, were what she herself had really thought deep down in her heart for years." 106 In addition to these unspoken common views, Marilla rereads (remembers) and narrates Anne's exploits as part of their shared narrative before 
briefly relating the story of her own failed romance with John Blythe.107 Anne's embodied reading has made Marilla a more thoughtful and compassionate reader of her own life, and by end of the novel, Mrs. Lynde avers that Marilla has become downright "mellow." 108

\section{"Which Would You Rather Be If You Had the Choice?": A Projection of Reading Stances}

In her study of quixotic novels, Birke explains the projection of reading stances as a tool for analyzing textual self-awareness and "to negotiate views of what it means to be a reader of fiction." 109 This concept builds upon Rabinowitz's view of the " authorial audience," a "more or less specific hypothetical audience" for whom authors "design their books rhetorically." 110 The notion of the authorial audience takes into account the impact of "readers' prior knowledge of conventions of reading" and how this knowledge impacts "their experiences and evaluations of the narratives they confront." 111 These projections of the authorial audience suggest stances toward reading through the interpretation of textual elements in light of discovering what they reveal about how we read. Additionally, characters who read contribute to these projections through their own attitudes and the way they contemplate the ties between the audience and author of a work.112 These stances toward reading embrace Rosenblatt's use of the term as that which "suggests a readiness to respond in a particular ... way."113 Rosenblatt situates these responses along a continuum with non-aesthetic, efferent reading (for information or to inform actions after reading) at one end, and aesthetic reading (concerned with the reader's experiences as she reads) on the other. Most reading occurs between these extremes, and the reader's focus, and by extension, her reactions, shift fluidly among the different facets of the text.114 Studying the reading stances projected in quixotic plots provides insight into the consumption of fiction by the novel's intended audience.

In Anne of Green Gables, three stances toward reading are projected: one moral, another aesthetic, and, a third, critical. These postures reflect the forms of the Platonic triad of truth, beauty, and goodness, as expressed by Anne in her question of Matthew on their first drive home, 115 "Which would you rather be if you had the choice-divinely beautiful or dazzlingly clever or angelically good?"116 André Narbonne sees the representation of the Platonic triad in the novel as the projection of a moral lesson that rejects Romanticism's exaggerated sentimentality and 
accepts duty as the ideal as readers "cease living in a false world of abandonment and find meaning instead in the real." 117 Instead of teaching a solely moral lesson, I argue that Anne's question, which Narbonne has described as "the epic question of the novel," 118 represents three stances toward reading: moral (goodness), aesthetic (beauty), and critical (truth).

A moral stance toward reading is most evident in the utilitarianism of the rural community of Avonlea where hard work and conformity take precedence over imagination; it is this stance that most closely mirrors Montgomery's apparent conformity to the domestic romance genre of her time. Our introduction to Avonlea is in the personage of Mrs. Rachel Lynde, a "notable housewife" whose "work was always done and well done." 119 Never is Mrs. Lynde idle, for in addition to the numerous groups she runs or in which she participates, she has time to knit quilts-"sixteen of them, as Avonlea housekeepers were wont to tell in awed voices." 120 Still, it is Marilla who most fully embodies this utilitarianism. Marilla's explanation of her and Matthew's decision to adopt a ten- or eleven-year-old boy is centred on both moral and practical considerations: "We decided that would be the best age-old enough to be of some use in doing chores right off and young enough to be trained up proper." 121 Marilla's original arguments against keeping Anne are solidly based in utilitarian considerations: "What good would she be to us?" she demands of Matthew.122 Once Marilla agrees that Anne may stay, she undercuts Matthew's observation of Anne as "such an interesting little thing" by insisting, "It' $d$ be more to the point if you could say she was a useful little thing." 123 Marilla's frustrations with Anne's flights of fancy, the polar opposite of her pragmatic understanding of duty and work, are borne out time and again: Anne beholds a beautiful tree where Marilla sees only fruit plagued by worms; 124 Anne's rapturous speech to Matthew about the upcoming Sunday-school picnic interferes with Marilla's timetable for Anne to work on her sewing; $125 \mathrm{Mr}$. and Mrs. Barry's invitation to take Anne to the concert with Diana and sleep over in the spare room collides with Marilla's fear that the outing will "unsettle her for a week." 126 Indeed, Marilla feels so bound to her duty of providing Anne with a moral upbringing that the authorial narrator observes she "was as fond of morals as the Duchess in Wonderland." 127 As Anne matures, she increasingly embraces a more utilitarian stance herself. She talks less and uses shorter words, 128 prepares "hot biscuits that were light and white enough to defy even Mrs. Rachel's criticism," 129 and even admits to Gilbert her stubbornness in holding a grudge.130 Her dutiful stance is most clearly portrayed in Anne's renunciation of her Avery Scholarship as she 
embraces her duty to Marilla, Green Gables, and, by extension, the community of Avonlea as its teacher. This is the expected denouement for readers of the domestic romance, and it foresees Anne's romance with Gilbert, upholding the social expectations and those of the genre at the same time that the other reading stances and Anne's strength as a female author undermine this status quo.

The second stance is aesthetic, and, in it, the reader's focus is on what she experiences during the act of reading itself.131 This stance envisions reading as an interactive experience that seeks an individual interpretation during the reading process, regardless of any practical information derived from a text. This is the approach that "indicates that the best kind of meaning is a personal meaning" 132 when reading and interpreting literature. It is such a response to reading that concerns Mrs. Barry when she bemoans that Diana "reads entirely too much." 133 Despite Mrs. Barry's concerns, reading is an important and integral activity practised by and shared among multiple characters in the novel. Anne's enactment of romantic reading reveals this aestheticism as she models her interpretation of her own world on her approach to reading literature and popular magazines. This is the reading experience of the here and now, of art for art's sake, and often, Anne's aesthetic interpretations of her world leave her enraptured, as in the case of the White Way of Delight, 134 the beauties of the shore road,135 her discoveries in and around the Green Gables property in her first fortnight at the Cuthberts', 136 and her response to the prima donna's performance in Charlottetown.137 Anne's attention to all things lovely is paramount, and in her first prayer she beseeches God, "please let me be good-looking when I grow up." 138 The flowers she adds to her hat on the way to Sunday school, 139 her desire to have a pretty dress with puffed sleeves, 140 and even her disastrous attempt to dye her hair a "beautiful raven black" 141 reveal Anne's eye for beauty. With her "love of wildflowers and celebration of beauty for beauty's sake, Anne is an aesthete" 142 whose appreciation for all things lovely is an enactment of the authorial narrator's "purple prose." 143 Anne also interprets others' actions with an eye to their aesthetic value, and sometimes finds them lacking-Mrs. Lynde's criticisms of her hair 144 and Gilbert's unwelcome nickname 145 being two prime examples.

Additionally, Anne's speech is punctuated with intertextual allusions and comments about her reading, revealing the centrality of art in her life. We know that she is reprimanded for reading Ben Hur during class because she is so enthralled with the romance of the chariot race, 146 and we know that other girls loan her novels. 147 
Anne discusses her reading with her friends, Miss Stacy, Mrs. Allan, and Marilla. Likewise, Anne and the other members of the Story Club read their creations to each other. These conversations and interactions reveal that for Anne, reading is not merely a cognitive act, but, rather, an intimately individualized activity fundamental to her daily life and that offers topics and content worthy of discussion in the reading community Anne inspires and builds. Kelly Blewett has described this attitude toward reading as one that "happens out in the world," 148 focusing on the Lily Maid adventure as her example. Anne's aesthetic interpretation and eventual dramatization of Tennyson's poem contrasts with the traditional approach to its study employed in the Avonlea school: "They had analyzed and parsed it and torn it to pieces in general until it was a wonder there was any meaning at all left in it for them." 149 Although Anne claims she is through with romance at the conclusion of this adventure, Matthew cautions Anne, "Don't give up all your romance." 150 This gentle admonition supports an aesthetic posture toward reading, for "to deny one's imaginative faculties and batten down to a totally practical existence is to kill one's soul." 151 This stance upholds the view that women's reading can bring them aesthetic pleasure and not only a moral by which to live.

The critical posture toward reading encourages the authorial audience to read deeper than the surface level, to look beyond the novel's apparent conformity to the norms of the domestic romance, and by extension, the patriarchal culture. Mrs. Lynde provides us with our first example of a critical reading stance. Seeing Matthew calmly and inexplicably driving by on a June day when he should be working, Mrs. Lynde knows "she would never rest until she had ferreted out the whys and wherefores thereof." 152 From the start, Mrs. Lynde serves as an example of the critical reader who digs below the surface. She models how to read when she pulls together all the various clues she has observed: the time of day and year; Matthew bedecked in his good clothes and driving the sorrel mare and buggy; the place settings and meal laid out on the table.153 When at last Marilla reveals the truth about Matthew's destination and purpose, Mrs. Lynde insists on an equally discerning stance toward understanding the expected orphan boy. She says: "You're bringing a strange child into your house and home, and you don't know a single thing about him nor what his disposition is nor what sort of parents he had nor how he's likely to turn out." 154 If we replace "child" with "novel" in Mrs. Lynde's observations, we can apply an equally critical stance toward reading and evaluating the unknown text before us. Likewise, the authorial narrator encourages a critical stance by differentiating between what an "ordinary observer" would have noticed 
of the young girl waiting at the train station and what an "extraordinary observer" would have deciphered.155 Marilla is also capable of understanding nuances, for we are told that she "was shrewd enough to read between the lines of Anne's history and divine the truth." 156 Matthew, the quintessential old bachelor, engages in a critical read of the sartorial when he observes Anne and her friends and realizes her dresses are somehow different.157 Anne's reads (assessments) of everyone from Mrs. Blewett as "a gimlet" 158 to Mrs. Barry as "obstinate" 159 and Superintendent Bell as unimaginative in his prayers 160 also project a critical and questioning posture toward reading. So sure is Anne of this questioning stance that she even calls into question Shakespeare's affirmation that "a rose by any other name would smell as sweet," doubting that "a rose would be as nice if it was called a thistle or a skunk-cabbage."161 Anne models the right to question the norms of her society, and this effectively parallels Montgomery's use of the domestic romance as a "safe space in which to write" while "[giving] ... sharp critical digs to a social system prejudiced against women." 162

The three stances toward reading projected in Anne of Green Gables reflect the epigraph to the novel from Browning's "Evelyn Hope." As a threshold to the novel, this epigraph comments both on the title and the text.163 The reference to Browning's poem recalls its speaker's final actions and words: he encloses a leaf in Evelyn Hope's lifeless hand, confident that she "will wake, and remember, and understand" its meaning.164 This image is an invitation to read the pages (leaves) with an eye to deeper understanding. Like Anne's "epic question" 165 about beauty, intellect, or goodness, the epigraph also mirrors the Platonic triad. The novel is multi-dimensional, and the epigraph invites the authorial audience to read it through the lens of the interwoven forms of spirit (goodness), fire (truth), and dew (beauty).

For the reader of Anne of Green Gables, these stances toward reading at first support and ultimately subvert the conventions of domestic romance and the dominant patriarchal system of Montgomery's time. Mary Rubio's study of the techniques Montgomery employs to undercut the very genre in which she writes underscores this ebb and flow between apparent conformity and subtle subversion. As Rubio points out, "This deviousness was necessary because many women readers would have been quite disturbed by a frontal attack on the social system which they took for granted ... but they were not averse to seeing oppressive patriarchal power structures satirized." 166 They can laugh at the scrapes Anne finds herself in as a result of quixotically assuming the creative authorship of her own life without feeling 
their own cultural norms challenged. Various of the strategies Rubio indicates are reminiscent of other quixotic plots: the use of oral storytelling, placing critical commentary in the mouths of characters of seemingly little importance such as an orphan child, a focus on ideas and characters over action, and a narrator who intrudes directly in the action. Ultimately, Montgomery has to cater to the demands of her reading public, and Anne must conform to the cultural norms of her time by marrying and starting a family. 167 Despite this generic ending, Anne's quixotism runs beneath the flow of the happy ending, encouraging her female readers to explore her story, and others, through multiple angles, and to become authors of their own narratives. Just as Anne enacts the Lily Maid scene, her own story "is akin to a costume for the girl reader to try on, a persona with which to play." 168 A multifaceted approach to reading and interpreting texts, as demonstrated by the stances projected in the novel, undercuts the apparent moral of the story and prescribed happy ending. 169170

\section{"No Ciphering Her Out by the Rules": Anne of Green Gables as a Quixotic Novel}

Reading Anne of Green Gables as a quixotic novel promotes a reflective interaction with the text, based on its portrayal of the processes of writing and reading. This performance accentuates the various stances toward reading projected in the novel, and, together, these postures provide a more complete interpretation than any single one alone. Just as Avonlea evolves from being "a community of atomized individuals," 171 the characters adopt each other's approaches so that the pragmatic and moralistic Marilla, the aesthetic Anne, and the critical Mrs. Lynde together form a whole, a community of readers. This emphasis on community is highlighted in the allusion to Tennyson's "The Palace of Art" in the final chapter.172 The authorial narrator references Tennyson's poem when she describes the setting before Anne as she walks home from the cemetery as "a haunt of ancient peace." 173 In the poem, a soul inhabits a rich palace in solitude, a condition and location that allow her infinite opportunities to explore beauty and intellect. Yet after a time, the soul begins to languish in her solitude, and she opts to abandon her "lordly pleasurehouse" for a modest cottage, hoping to again live in community "with others." 174 Anne, like the soul of the poem, embraces the beauty of the community before her, and the duty and truth that accompany it, and "she gratefully opened the gates of her soul to it." 175 Stephen Railton points to the tension between solitary artistic production and awareness of audience, observing that "literary creations should 
mean finding and freely enjoying a territory of one's own imagination, but in fact it means moving in just the opposite direction: toward others." 176 As Elizabeth Epperly has observed, "Anne is not meant to live forever in appreciation of scenery and tranquility alone; she is destined to interact with many others." 177 Anne's acceptance of her duty and movement away from her solitary imaginings accentuate this paradox of authorship, and the multiple reading stances underscore the novel's apparent conformity to the genre of domestic romance.

Despite the temptation to interpret the novel as a moral lesson, of the three stances toward reading projected in Anne of Green Gables (moral, aesthetic, and critical), none prevails over any other. Instead, the stances are interwoven throughout this quixotic plot and reflect the "to-and-fro movement of the attention from one aspect to another of the responses activated by the text." 178 The characters representing these different postures constantly check each other to underscore the multi-faceted and fluid nature of reading responses: the aesthetically sensitive Anne reminding Mrs. Lynde that unfiltered criticism of her red hair is unwarranted; Mrs. Lynde undermining Marilla's pure utilitarianism by becoming Matthew's accomplice in making a beautiful, puffed-sleeve dress for Anne; and Anne's hair being shorn at Marilla's hand, following her attempts to dye it, are symbolic of trimming away the excesses of her aestheticism.

Although Anne's enactments of reading skirt the line between fact and fiction, she generally recognizes her stories and daydreams for what they are. She understands that her fancies are just that-until they intrude fully upon her physical reality, as in the Haunted Wood episode.179 Then, the authorial narrator reveals that "her terror was very real," 180 and as the title of that chapter suggests, Anne's "Good Imagination" has "Gone Wrong." Although Anne's unrestrained efforts to enact a ghost story in a Gothic setting succeed in frightening her, it is not her aestheticism itself that has "gone wrong," but, rather, her one-dimensional approach to reading and creating a story. This episode significantly occurs on Anne's one-year anniversary at Green Gables, and it serves as a reminder to strike the balance among the reading stances projected throughout the novel. Anne's endeavours to create art for art's sake are not only criticized by Marilla, but also by the authorial narrator in the selection of this intertitle. Anne's imagination has led her astray, not because of her aestheticism and creativity, but, rather, because it embodies a single posture toward reading. This intertitle reminds us not to embrace a single reading stance, nor to confuse Montgomery's "medium" (the domestic romance) "with her 
message." $\underline{181}$

This multi-faceted model to reading the writer and writing the reader, to paraphrase Birke's title, recalls Mrs. Lynde's later words to Marilla of Anne:

I never would have thought she'd have turned out so well that first day I was here three years ago ... I did make a mistake judging Anne, but it weren't no wonder for an odder, unexpecteder witch of a child there never was in this world, that's what. There was no ciphering her out by the rules that worked with other children. It's nothing short of wonderful how she's improved these three years, but especially in looks. She's a real pretty girl got to be ....182

It is Mrs. Lynde, the "all-seeing eye" 183 and overly critical reader of the first scene, who blends the three stances in these lines: she acknowledges the limits of her criticism while recognizing both Anne's usefulness and her beauty. Mrs. Lynde reminds us that one-dimensional attitudes toward reading-those "that worked with other children"184-will fall short in our interpretations of Anne who is in a category all her own. Montgomery works subtly within the domestic romance genre to offer a rich representation of the female author and women readers. Reading Anne of Green Gables as a quixotic novel illustrates how Montgomery's rhetoric of a performance of authorship embodies moral, aesthetic, and critical reading stances to explore both writing and reading as creative endeavours.

About the Author: Dr. Julie A. Sellers, a specialist in adult second language acquisition and Latin American popular culture and identity, is an Associate Professor of World and Classical Languages and Cultures (Spanish) at Benedictine College. She is also a Federally Certified Court Interpreter (Spanish/English). Dr. Sellers has published three books on Dominican music and identity, and on language acquisition and interpreting skills in a variety of publications. In addition to these topics, Dr. Sellers has applied her work in literature and identity to studies of Anne of Green Gables. She was the 2017 Kansas World Language Association's Teacher of the Year. 
Acknowledgements: The author wishes to thank Dr. Michael Stigman and Prof. Veronica Charbonnet for reading early drafts of this article; Dr. Filiberto Mares Hernández, P.J. Vaske, and Christopher Renna for reading the original conference proposal based on this study; librarian Jane Schuele who helped me obtain a number of sources through Interlibrary Loan; the Atchison Public Library for allowing me to share my research with the local community; artist Claire Schroettner for the beautiful artwork that accompanies this article; and my dog, Mozzie, for sitting at my feet while I read for this study. Special thanks to Dr. Lesley Sieger-Walls for years of shared dreams, ambitions, and now memories based on our Anne-inspired escapades.

Banner image derived from Drawing of "Anne of Green Gables and Don Quixote." 2019. Claire Schroettner.

- 1 Birke, Writing 32.

- 2 Birke 43.

- 3 Phelan, "Authors" 2.

- 4 Railton, Authorship 4.

- $\underline{5}$ Lanser, Fictions 16.

- 6 Fox, Flaubert 46.

- 7 Larubia-Prado, Don Quijote 340.

- 8 Laurbia-Prado, 334.

- 9 Brown, "The Quixotic Fallacy" 251.

- 10 Fernández-Morera, “Cervantes” 405.

- 11 Fernández-Morera 409.

- 12 Haley, "Narrator."

- 13 Cervantes, Don Quixote 620-42.

- 14 Birke, 24.

- 15 Ross, "Calling."

- 16 Gaylord, “Don Quixote's" 80-81.

- 17 Gammel, "Wildwood Roses" 4.

- 18 Rubio, "Subverting" 8, 12.

- 19 Rubio, "Subverting" 7-8.

- 20 Rubio, "Subverting" 8.

- 21 Fox 18.

- 22 Haley 164.

- $\underline{23}$ Rubio, "Subverting" 13. 
- 24 Birke 177.

- $\underline{25}$ Given the intended English-speaking audience for this article, all quotations are from Edith Grossman's translation to the English of Don Quixote .

- $\underline{26}$ Cervantes 21 .

- 27 Cervantes 21.

- 28 Birke 21.

- 29 Wlimshurst.

- 30 Norvillo-Corvalán, “Androgynous Desire" 2.

- 31 Norvillo-Corvalán 4.

- 32 Montgomery, Annotated Anne 295.

- 33 Walley-Beckett.

- 34 Epperly, Fragrance 11.

- 35 Montgomery 52.

- 36 Montgomery 52-56.

- 37 Montgomery 63.

- 38 Montgomery 103.

- 39 Fox 119.

- 40 Martínez, “Don Quijote” 48.

- 41 Oriel, "Yo Sé" 75, 80.

- 42 Montgomery 67.

- 43 Montgomery 69.

- 44 Montgomery 109.

- 45 Gammel, Looking 170.

- 46 Steffler, "Anne" 155.

- 47 Montgomery 81.

- 48 Ross.

- 49 Montgomery 160.

- 50 Sugars, "Matthew's School" 115.

- 51 Gaylord 74.

- 52 Sugars 111.

- 53 Montgomery 177-90.

- 54 Montgomery 253.

- 55 Montgomery 288.

- 56 Montgomery 293-302.

- 57 Fox 45.

- 58 Montgomery 122.

- 59 Montgomery 123. 
- 60 Montgomery 156.

- 61 Montgomery 140.

- 62 Montgomery 191.

- 63 Montgomery 193.

- 64 Montgomery 192.

- 65 Montgomery 204.

- 66 Montgomery 294.

- 67 Montgomery 276.

- 68 Montgomery 300-301.

- 69 Montgomery 116.

- 70 Montgomery 167.

- 71 Montgomery 277.

- 72 Montgomery 346.

- 73 Rosenblatt, The Reader 28.

- 74 Railton 18.

- 75 Cervantes 65-69.

- 76 Fernández-Morera 409.

- 77 Haley.

- 78 Genette, Paratexts 2.

- 79 Genette.

- 80 Titles of the first three chapters are "Mrs. Rachel Lynde is Surprised," "Matthew Cuthbert is Surprised," and "Marilla Cuthbert is Surprised."

- 81 Birke 40.

- 82 Montgomery 39.

- 83 Montgomery 40.

- 84 Montgomery 45.

- 85 Montgomery 45.

- 86 Montgomery 76.

- 87 Montgomery 78.

- 88 Montgomery 61.

- 89 Montgomery 72 .

- 90 Montgomery 251.

- 91 Montgomery 251.

- 92 Montgomery 182, 280.

- 93 Montgomery 178.

- 94 Rubio, “Anne" 74.

- 95 Montgomery 182. 
- 96 Montgomery 182-84.

- 97 Montgomery 227-28.

- 98 Waterston, Kindling Spirit 36.

- 99 Montgomery 280-82.

- 100 Montgomery 282.

- 101 Gubar, "'Where.'”

- 102 Montgomery 333.

- 103 Montgomery 43.

- 104 Montgomery 67.

- 105 Montgomery 175.

- 106 Montgomery 133.

- 107 Montgomery 384-85.

- 108 Montgomery 175.

- 109 Birke 5.

- 110 Rabinowitz, Before Reading 21.

- 111 Rabinowitz 3.

- 112 Birke 39.

- 113 Rosenblatt 43.

- 114 Rosenblatt 37.

- 115 Narbonne, "Carlylean Sentiment," 435-36.

- 116 Montgomery 58.

- 117 Narbonne 434.

- 118 Narbonne 435.

- 119 Montgomery 39.

- 120 Montgomery 40.

- 121 Montgomery 45-46.

- 122 Montgomery 73.

- 123 Montgomery 96.

- 124 Montgomery 76.

- 125 Montgomery 143.

- 126 Montgomery 214.

- 127 Montgomery 106.

- 128 Montgomery 331-32.

- 129 Montgomery 325.

- 130 Montgomery 394.

- 131 Rosenblatt 25.

- 132 Blewett, “'An Unfortunate'” 281. 
- 133 Montgomery 137.

- 134 Montgomery 58-59.

- 135 Montgomery 88.

- 136 Montgomery 112.

- 137 Montgomery 310.

- 138 Montgomery 99.

- 139 Montgomery 129.

- 140 Montgomery 127-28.

- 141 Montgomery 290.

- 142 Gammel, Looking 171.

- 143 Rubio, Lucy Maud 3.

- 144 Montgomery 114-15.

- 145 Montgomery 167.

- 146 Montgomery 316-17.

- 147 Montgomery 200, 317-18.

- 148 Blewett 277.

- 149 Montgomery 295.

- 150 Montgomery 302.

- 151 Rubio, “Anne" 74.

- 152 Montgomery 39.

- 153 Montgomery 40-43.

- 154 Montgomery 46.

- 155 Montgomery 51.

- 156 Montgomery 89.

- 157 Montgomery 265-66.

- 158 Montgomery 95.

- 159 Montgomery 190.

- 160 Montgomery 131, 256.

- 161 Montgomery 85.

- 162 Rubio, "Subverting" 19.

- 163 Genette 56-60.

- 164 Browning, "Evelyn Hope" 64.

- 165 Narbonne 435.

- 166 Rubio, "Subverting" 19.

- 167 Rubio, "Subverting" 28.

- 168 Blewett 276.

- 169 Blewett 279. 
- 170 Rubio, "Subverting" 27.

- 171 Narbonne 436.

- 172 Blewett 288.

- 173 Montgomery 394.

- 174 Tennyson, "Palace."

- 175 Montgomery 394.

- 176 Railton 22.

- 177 Epperly 36.

- 178 Rosenblatt 37.

- 179 Sugars 111.

- 180 Montgomery 231.

- 181 Rubio, "Subverting" 16.

- 182 Montgomery 325.

- 183 Montgomery 40.

- 184 Montgomery 325.

Back to top

\section{Article Info}

Copyright: Julie A. Sellers, 2019. This work is licensed under a Creative Commons Attribution 4.0 International License (Creative Commons BY 4.0), which allows the user to share, copy and redistribute the material in any medium or format and adapt, remix, transform and build upon the material for any purpose, even commercially, PROVIDED the Licensor is given attribution in accordance with the terms and conditions of the CC BY 4.0.

Peer reviewed

Yes

Works Cited

Northanger Abbey

Writing the Reader: Configurations of a Cultural Practice in the English Novel An Unfortunate Lily Maid: Transgressive Reading in Anne of Green Gables

The Quixotic Fallacy

Evelyn Hope

Don Quixote

The Fragrance of Sweet-Grass: L.M. Montgomery's Heroines and the Pursuit of Romance

Cervantes and the Aesthetics of Reception 
Madame Bovary

Flaubert and Don Quijote: The Influence of Cervantes on Madame Bovary Looking for Anne: How Lucy Maud Montgomery Dreamed Up A Literary Classic Wildwood Roses and Sunshine Girls: The Making of Anne of Green Gables as a Popular Romance

Don Quixote's New World of Language

Paratexts: Thresholds of Interpretation

Where is the Boy? : The Pleasures of Postponement in the Anne of Green Gables

Series

The Narrator in Don Quijote: Maese Pedro's Puppet Show

Ulysses

Fictions of Authority: Women Writers and Narrative Voice

Don Quijote as Performance: The Sierra Morena Adventure

The Female Quixote, or The Adventures of Arabella

Don Quijote o la invención del lector

Atonement

The Annotated Anne of Green Gables

Carlylean Sentiment and the Platonic Triad in Anne of Green Gables

Androgynous Desire: Flaubert, Joyce, Puig, and the Tradition of the Female Quixote

'Yo sé quién soy': How don Quijote Does Things with Words (Part I, chaps. 1-5)

Authors, Resources, Audiences: Toward a Rhetorical Poetics of Narrative

Before Reading: Narrative Conventions and the Politics of Interpretation

Authorship and Audience: Literary Performance in the American Renaissance

The Reader, the Text, the Poem: The Transactional Theory of the Literary Work

Calling Back the Ghost of the Old-Time Heroine: Duncan, Montgomery, Atwood, Laurence, and Munro

Anne of Green Gables: The Architect of Adolescence

Subverting the Trite: L.M. Montgomery's room of her own

Anne in a Globalized World: Nation, Nostalgia, and Postcolonial Perspectives of Home

Matthew's school of critics: Learning to Read Anne of Green Gables

The Palace of Art

Kindling Spirit: L. M. Montgomery's Anne of Green Gables

L. M. Montgomery's Use of Quotation and Allusion in the 'Anne Books'

Your Will Shall Decide Your Destiny 


\section{Works Cited}

Austen, Jane. Northanger Abbey. From a 1818 edition. The Floating Press, 2009.

Birke, Dorothee. Writing the Reader: Configurations of a Cultural Practice in the English Novel. De Gruyter, 2016.

Blewett, Kelly. "'An Unfortunate Lily Maid': Transgressive Reading in Anne of Green Gables." The Lion and the Unicorn, vol. 39, no. 3, 2015, pp. 275-93.

Brown, Gillian. "The Quixotic Fallacy." Novel: A Forum on Fiction, vol. 32, no. 2, 1999, pp. 250-73.

Browning, Robert. "Evelyn Hope." Lyrics of Life, Ticknor and Fields, 1917, pp. 62-64.

Cervantes, Miguel de. Don Quixote. Translated by Edith Grossman, Harper Collins, 2003.

Epperly, Elizabeth Rollins. The Fragrance of Sweet-Grass: L.M. Montgomery's Heroines and the Pursuit of Romance. 1992. U of Toronto P, 2014.

Fernández-Morera, Darío. "Cervantes and the Aesthetics of Reception." Comparative Literature Studies, vol. 18, no. 4, 1982, pp. 405-419.

Flaubert, Gustave. Madame Bovary. 1857. Penguin, 1995.

Fox, Soledad. Flaubert and Don Quijote: The Influence of Cervantes on Madame Bovary. Sussex Academic P, 2008.

Gammel, Irene. Looking for Anne: How Lucy Maud Montgomery Dreamed Up a Literary Classic. Key Porter, 2008.

---. "Wildwood Roses and Sunshine Girls: The Making of Anne of Green Gables as a Popular Romance." 100 Years of Anne with an "e": The Centennial Study of Anne of Green Gables, edited by Holly Blackford, U of Calgary P, 2009, pp. 1-21.

Gaylord, M.M. “Don Quixote's New World of Language." Cervantes: Bulletin of the Cervantes Society of America, vol. 27, no. 1, 2007, pp. 71-94.

Genette, Gerard. Paratexts: Thresholds of Interpretation. Cambridge UP, 1997. 
Gubar, Marah. "'Where Is the Boy?': The Pleasures of Postponement in the Anne of Green Gables Series." The Lion and the Unicorn, vol. 25, no. 1, Jan. 2001, pp. 47-69.

Haley, George. "The Narrator in Don Quijote: Maese Pedro's Puppet Show." MLN, vol. 80 , no. 2, Mar. 1965, pp. 145-65.

Joyce, James. Ulysses. 1934. Random House, 1946.

Lanser, Susan Sniader. Fictions of Authority: Women Writers and Narrative Voice. Cornell UP, 1992.

Larubia-Prado, F. "Don Quijote as Performance: The Sierra Morena Adventure." Revista canadiense de estudios hispánicos, vol. 33, no. 2, 2009, pp. 335-56.

Lennox, Charlotte. The Female Quixote, or the Adventures of Arabella. 1752. Oxford UP, 1970.

Martínez, Gustavo. “Don Quijote o la invención del lector." Humanidades: Revista de la Universidad de Montevideo, vol. 5, no. 1, 2005, pp. 43-60.

McEwan, Ian. Atonement. Anchor, 2003.

Montgomery, L.M. The Annotated Anne of Green Gables, edited by Wendy E. Barry, Margaret Anne Doody, and Mary E. Doody Jones, Oxford UP, 1997.

Narbonne, André. "Carlylean Sentiment and the Platonic Triad in Anne of Green Gables." American Review of Canadian Studies, vol. 44, no. 4, 2014, pp. 433-47.

Norvillo-Corvalán, Patricia. “Androgynous Desire: Flaubert, Joyce, Puig, and the Tradition of the Female Quixote." The Modern Language Review, vol. 107, no. 1, 2012, pp. 1-19.

Oriel, Charles. "'Yo sé quién soy': How Don Quijote Does Things with Words (Part I, Chaps. 1-5)."Cervantes: Bulletin of the Cervantes Society of America, vol. 29, no. 1, 2009, pp. 57-83.

Phelan, James. "Authors, Resources, Audiences: Toward a Rhetorical Poetics of Narrative." Style, vol. 52, no. 1-2, 2018, pp. 1-34.

Rabinowitz, Peter J. Before Reading: Narrative Conventions and the Politics of Interpretation. Cornell UP, 1987. 
Railton, Stephen. Authorship and Audience: Literary Performance in the American Renaissance. Princeton UP, 1991.

Rosenblatt, Louise M. The Reader, the Text, the Poem: The Transactional Theory of the Literary Work. Southern Illinois UP, 1994.

Ross, Catherine Sheldrick. "Calling Back the Ghost of the Old-Time Heroine: Duncan, Montgomery, Atwood, Laurence, and Munro." Studies in Canadian Literature, vol. 4, no. 1, 1979, https://journals.lib.unb.ca/index.php/SCL/article/view/7907/8964In.

Rubio, Mary Henley. "Anne of Green Gables: The Architect of Adolescence." Such a Simple Little Tale: Critical Responses to L.M. Montgomery's Anne of Green Gables, edited by Mavis Reimer, The Children's Literature Association and Scarecrow $P$, 1992, pp. 65-82.

---. Lucy Maud Montgomery: The Gift of Wings. Doubleday Canada, 2008.

---. "Subverting the Trite: L.M. Montgomery's Room of Her Own." Canadian Children's Literature/Littérature canadienne pour la jeunesse, vol. 68, 1992, pp. 6-39.

Steffler, Margaret. "Anne in a 'Globalized' World: Nation, Nostalgia, and Postcolonial Perspectives of Home." Anne's World: A New Century of Anne of Green Gables, edited by Irene Gammel and Benjamin Lefebvre, U of Toronto P, 2010, pp. 150-65.

Sugars, Cynthia. "Matthew's School of Critics: Learning to Read Anne of Green Gables." Anne Around the World: L.M. Montgomery and Her Classic, edited by Jane Ledwell and Jean Mitchell, McGill-Queens UP, 2013, pp. 106-19.

Tennyson, Alfred Lord. "The Palace of Art." 1901. The Victorian Web http://www.victorianweb.org/authors/tennyson/palacetxt.html.

Walley-Beckett, Moira, creator. "Your Will Shall Decide Your Destiny." Anne with an E, Pelican Ballet/Northwood Entertainment, 2017.

Waterston, Elizabeth Hillman. Kindling Spirit: L.M. Montgomery's Anne of Green Gables. ECW Press, 1993. Canadian Fiction Studies 19.

Wilmshurst, Rea. "L.M. Montgomery's Use of Quotation and Allusion in the 'Anne' Books." Canadian Children's Literature/Littérature canadienne pour la jeunesse, vol. 56, 1989, pp. 15-45. 